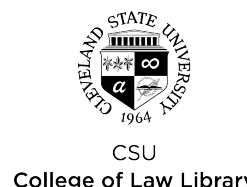

Cleveland State University

College of Law Library

\title{
EngagedScholarship@CSU
}

$1-15-2016$

\section{'Something Wicked This Way Comes': Political Correctness and the Reincarnation of Chairman Mao}

David R. Barnhizer

Cleveland State University, d.barnhizer@csuohio.edu

Follow this and additional works at: https://engagedscholarship.csuohio.edu/fac_articles

Part of the Law Commons

How does access to this work benefit you? Let us know!

\section{Repository Citation}

Barnhizer, David R., "'Something Wicked This Way Comes': Political Correctness and the Reincarnation of Chairman Mao" (2016). Law Faculty Articles and Essays. 822.

https://engagedscholarship.csuohio.edu/fac_articles/822

This Article is brought to you for free and open access by the Faculty Scholarship at EngagedScholarship@CSU. It has been accepted for inclusion in Law Faculty Articles and Essays by an authorized administrator of EngagedScholarship@CSU. For more information, please contact research.services@law.csuohio.edu. 


\section{CLEVELAND-MARSHALL COLLEGE OF LAW}

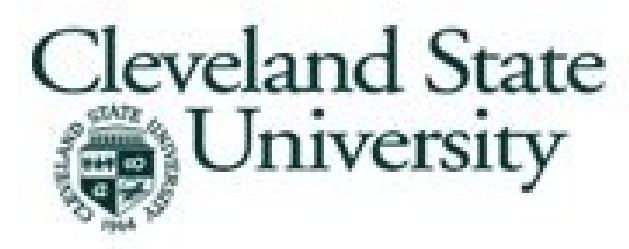

Research Paper 16-291

January 2016

\section{"Something Wicked This Way Comes": Political Correctness and the Reincarnation of Chairman Mao \\ by \\ David Barnhizer}

Professor Emeritus of Law, Cleveland-Marshall College of Law

Working Paper

This paper can be downloaded without charge from the Social Science Research Network electronic library: 


\title{
“Something Wicked This Way Comes": Political Correctness and the Reincarnation of Chairman Mao
}

\author{
David Barnhizer
}

\section{Mao's Red Guards and the “Wicked Wisdom” of Lesley Gore}

There could not possibly be any parallel between the actions of Mao Tse Tung's young Red Guard zealots and the intensifying demands of identity groups in the US and Europe that all people must conform to their version of approved linguistic expression or in effect be condemned as "reactionaries" and "counter-revolutionaries" who are clearly "on the wrong side of history". Nor, in demanding that they be allowed to effectively take over the university institution and its curriculum, while being empowered to approve the staffing of faculty and administrative positions with people who think like them, while others are subjected to "re-education" sessions that "sensitize" them into the proper way to look at the world's reality, should we judge students and protesters such as those who submitted fifty Demands to the University of North Carolina to be in any way akin to the disastrous, repressive, immature and violent members of the Red Guard who abused China between 1966 and 1976. Nonetheless, though it would be unfair to compare the two movements, the Cultural Revolution does send out a warning we should perhaps spend a little time thinking about lest we repeat some of its errors. A brief descriptive capsule appears below.

The first targets of the Red Guards included Buddhist temples, churches and mosques, which were razed to the ground or converted to other uses. Sacred texts, as well as Confucian writings, were burned, along with religious statues and other artwork. Any object associated with China's pre-revolutionary past was liable to be destroyed. In their fervor, the Red Guards began to persecute people 
deemed "counter-revolutionary" or "bourgeois," as well. The Guards conducted so-called "struggle sessions," in which they heaped abuse and public humiliation upon people accused of capitalist thoughts (usually these were teachers, monks and other educated persons). These sessions often included physical violence, and many of the accused died or ended up being held in reeducation camps for years. ${ }^{1}$

I never thought I would be starting off an analysis by citing a description of the Red Guard's re-education and thought control actions in Mao Tse Tung's 1966-1976 Cultural Revolution and the words of Lesley Gore's "You Don't Own Me" song. But in the context of what is going on in American and European societies involving the comprehensive strategy to control freedom of speech through formal and informal mechanisms of power, Gore's slightly edited (for length) language seems highly appropriate. Her in-yourface paean to independence of thought and action captures what we face.

[D]on't tell me what to do Don't tell me what to say...

I don't tell you what to say Oh, don't tell you what to do So just let me be myself That's all I ask of you

1 "What Was the Cultural Revolution?", http://asianhistory.about.com/od/modernchina/f/What-Was-The-CulturalRevolution.htm 
I'm free and I love to be free

To live my life the way I want

To say and do whatever I please ${ }^{2}$

If the idiocy and well-intentioned malevolence of the Red Guards and Ms. Gore's eloquent protest against being controlled in her thought, language and action don't offer enough satisfaction we can add the feeling evoked by a 1983 Disney movie titled "Something Wicked This Way Comes" based on a 1962 Ray Bradbury novel of the same name. "Something Wicked" reflects an inchoate fear of a dark and evil force moving steadily but invisibly toward a group of youthful innocents in a small town. Although some might not like the parallel it is my position that in America today, and Europe for that matter, something wicked is coming our way and its wickedness is masked by hidden agendas and even good intentions.

Part of that developing evil is the campaigns by many groups to not only label any view other than their own as hate speech, vile, reprehensible and so forth but to savagely pursue and punish anyone who fails to give obeisance to their positions. This is being done by heckling, seeking to destroy the careers of those who don't cave in to their demands, issuing threats, labeling individuals and institutions with powerful accusations for which it is largely impossible to "prove the negative", and demanding resignations or firings and other contemptible behavior that is claimed to "offend", or denies the censors their "safe spaces". The irony is that we can even assume that these tactics by people insistent on having their own "safe spaces" create traumatic experiences that will generate a need for "trigger" warnings for the affected persons for the rest of their lives.

What is occurring is not new but it is gaining in sophistication, scope, viciousness and intensity as fanatics learn how to use the Internet as a weapon. Peter Drucker has described what is happening within our

${ }^{2}$ Lesley Gore - "You Don't Own Me Lyrics", MetroLyrics. 
political and social system as the "new realities" of an increasingly pluralist democracy, explaining that: "The new pluralism ... focuses on power. It is a pluralism of single-cause, single-interest groupsthe "mass movements" of small but highly disciplined minorities. Each of them tries to obtain through power what it could not obtain through numbers or through persuasion. Each is exclusively political." 3

\section{It Is All About Power, Control and Advantage for One's Identity Group}

I agree with Ted Cruz about few things. But one of them is captured by an op-ed he published in London's Guardian. In that report it was observed that: "Republican presidential hopeful Ted Cruz has condemned the growing wave of campus protests in the US as a product of "pampered teenagers who are scared of an idea that challenges their world view". Cruz suggested: "I think it is more than a little ironic that the activities are targeting a leftist progressive Democrat like Woodrow Wilson," [Cruz said] "I am not a fan of Woodrow Wilson. I think his policies did a great deal of damage to this country, but that being said I think the protesters at Princeton who are embracing this radical political correctness where they are claiming a right to be offended at anything they deem contrary to their vision of the world - that is completely antithetical to the mission of a university." 4

\footnotetext{
3 Peter Drucker, The New Realities 76 (Harper \& Row 1989). In The Horizontal Society at vii, Lawrence Friedman discussed a diverse range of issues, beginning with what he refers to as the rise of "identity wars and identity politics".

4 "'Pampered teenagers': Ted Cruz condemns Princeton campus protesters", A black professor's response to Cruz quickly appeared. See, Justin Hansford, "Ted Cruz's 'pampered teens' strike at white supremacy's heart in campus protests", http://www.theguardian.com/us-news/2015/dec/02/ted-cruz-princeton-protestspolicing-syrian-refugees. Included in Hansford's analysis is: "black students bear the weight of the theoretical work of unravelling the thread of the intellectual project. Black students must continue to protest, but they also must continue to re-theorize the structure and values of the academy, globally, in the $21^{\text {st }}$ century. Black students must
} 
Daniel Bell warned that: "Ideology is the conversion of ideas into social levers." 5 He added: "For the ideologue, truth arises in action, and meaning is given to experience by the "transforming moment." He comes alive not in contemplation, but in 'the deed.", 6 This is not (at least in the traditional sense) the language of the scholar or teacher, but of activists and ideologues. In saying this I admit I have spent much of my life as an activist but I am also a teacher and a scholar and there are times when ideology and activism goes too far and endangers other fundamentally important values such as the integrity of the Rule of Law and social discourse. We have entered such a moment.

Who better to highlight the price we pay if we fail to protect freedom of speech than Salman Rushdie. Rushdie expressed his horror at the British government's failure to even bother criticizing violent and threatening Sikh protesters in the UK who forced the closure of Behzti, a play depicting rape and murder in a Sikh temple. Rushdie, forced into hiding for years after Ayatollah Khomeini issued a fatwa calling for his death for writing The Satanic Verses, said government ministers should have protected freedom of expression. Instead, he said: "It's been horrifying to see the response. It is pretty terrible to hear government ministers expressing approval of the ban and failing to condemn the violence when they should be supporting freedom of expression." 7

In saying that political correctness and language control have gone too far I am in no way making light of the continuing discriminations that exist in American society. At the beginning of the 1980s George

continue to question the foundations of their schools. Who decides the curriculum? Who teaches? Who are the buildings named after? Who has final say over the budget?"

${ }^{5}$ Daniel Bell, The End of Ideology 370-371 (New York 1960). George Gilder, Wealth and Poverty 107 (Bantam ed., 1982).

${ }^{6}$ Bell, The End of Ideology, id.

${ }^{7}$ Lee Glendinning, "Rushdie attacks closure of Sikh play”, December 27, 2004, The Guardian. 
Gilder began his argument in Wealth and Poverty with the claim that the problem of racial discrimination had been overcome (circa 1980) and we can better focus on other matters. Gilder's claim was a false and self-serving assertion three decades ago, and remains false today. It was a tactic uttered in support of Republican ideology and political agendas aimed at the civil rights movement and social spending. Democrats and political groups of the Left have now far exceeded Republicans in their ability to manipulate, intimidate and assign new ways to blame others for social wrongs they have failed to mitigate and may even have worsened through prior policy choices. ${ }^{8}$

We can talk endlessly about due process and fairness, justice, respect, diversity or multiculturalism but what we are really experiencing is a quest for the Holy Grail of power by fractured identity groups located across all political dimensions. The advocates may use the language of truth, justice, fairness and so forth but in virtually all contexts those are merely devices the propagandists of competing political movements and identity groups are using in support of their efforts to acquire power and its entitlements. Even though in many instances the aims and intentions of the advocates are good on some level, much of what is occurring in actual practice is the behavior of fanatics and extremists. The level of intolerance within their camps is extreme and the tactics increasingly reprehensible.

In his book, Power, Adolf Berle captured the reality of social movements and their quest for institutional control. The recognition that power requires control of decision-making institutions and the ability to set and enforce rules that serve your interests has created a competition to occupy the sources of power and define the rules of decision to ensure that particular interest group preferences are reflected in the institutional choices.

\footnotetext{
${ }^{8}$ George Gilder, Wealth and Poverty 107 (Bantam ed., 1982).
} 
Berle warned that control of institutions is the only way by which people can extend their power beyond the limited reach of their fists or guns. For previously subordinated groups this is particularly important because those they are seeking to supplant tend to possess greater power and the only effective strategy in a Rule of Law system has been to capture the mechanisms by which law is created, interpreted, applied and enforced. Obviously, this means that those seeking to capture the ability to dictate rules to others or to protect against others' control over their interests must implement effective strategies to gain possession of the institutions that make and enforce the rules or laws. ${ }^{9}$ Once this is done, creating linguistic behaviors that are defined as violating the new rules relating to treatment of your protected class becomes an important element of control and intimidation.

\section{The "Flower Children" Unfortunately Reproduced and Created a "Less Than Brave New World"}

As I write this essay I just read a painfully appropriate Mallard Fillmore comic by Bruce Tinsley in my local newspaper. In only a single panel Tinsley captures the essence of many students' expectations from their universities. A university professor reads out loud from a student's "essay” as follows. "I'd like to read Kevin's essay... "Give Me an 'A' on this essay ... Or the campus will burn..." [The Professor adds] "That's the entire essay ... Wonderfully concise, with vivid imagery, Kevin!" 10

An interesting thing is that we don't know if the teacher is using Kevin's words as a critique to demonstrate its absurdity or if he is voicing true appreciation for its Wittgensteinian conciseness and precision. If he is using Kevin as a foil to demonstrate how not to fulfill the assignment then he will have insensitively violated Kevin's

\footnotetext{
${ }^{9}$ Adolf A. Berle, Power at 92 (1967).

${ }^{10}$ Bruce Tinsley, "Mallard Fillmore", The News-Press, Wednesday, December 2, 2015 at E1.
} 
"safe space" and dehumanized him by victimizing Kevin and making him "feel bad" and even "threatened" because of the consequences of turning in a failing essay and even the attempt to blackmail and extort a grade from the class. Along with this goes the fact that he used Kevin as a "thing” for the purposes of the classes' learning process.

On the other hand if the teacher is actually praising Kevin he is offending the entire purpose and responsibility of the university as institution to instill critical thought and useful knowledge in the students who are subject to the institution's control during a vital moment in their intellectual development. This doesn't even begin to develop the issue of the negative educational impact on students in terms of their sense of how to write an essay, or whether one can obtain what is desired at any situation in life through threats of violence. By the way, I wonder if Kevin's professor felt threatened or thought his classroom "safe space" was violated?

Under the heading of "you reap what you sow" I believe a great deal of the questionable behavior now taking place has its roots in movements first launched four or five decades ago. The decades of the 1960s and 1970s were seen by many as a celebration of caring, heightened social consciousness, delightful pacifist "Flower Children", sensitivity, sweetness and "light" to the point it came to be labeled rather pejoratively as "touchy-feely".

Those of us who were "seasoned" with the orientations of that time were sensitive to others' "auras" and we learned how to "grok" from reading Robert Heinlein's classic SciFi novel Stranger in a Strange Land. We were "sensitive", committed to Peace ("Man"), participated in civil rights and anti-war marches and protests and above all, like Bill Clinton "felt the pain" of those not as fortunate as ourselves and expected the same treatment. Unlike Bill Clinton, however, many "Rainbow Warriors" did actually "inhale" and their children and grandchildren are "sucking in" "righteous weed" and ingesting the best designer drugs. 
As for education, we learned that creating "schools without failure" was the least painful way for students to pass through school even if they didn't really learn anything during that journey. After all, we knew that classical education was designed to make us into "just another brick in the wall” and the truth was Pink Floyd's classic articulation that "we don't need no education" and it was best if "Teachers! Leave them kids alone!" Pursuant to the value systems of that historical moment at least no one suffered the psycho-traumatic pain of being "judged" as not as skilled at something as anyone else, no one lost out due to the emotionally damaging stresses of competition, and once we learned to make sure no one ever was made to "feel bad" then everything was "copacetic, Dude".

We are now paying the price for the sins of the 1960s and 1970s. Decades of "enlightened" strategies such as "social passes" in school, inflated grades in no way related to the merit of a student's performance, granting students the power to judge the usefulness and quality of a teacher's performance even though the students knew little or nothing about the significance of what they were supposed to learn, have all contributed to the creation of a large class of people who aren't very well educated. But they are absolutely certain of their own self worth and expect and demand rewards without performance and trophies for just showing up.

\section{Identity Groups Comprised of "Victims" and "Hyper-Sensitives" Are Now Being Joined by Marginalized "White Maleness”}

The policies introduced in the 1960s and 1970s and expanded in the ensuing decades have created a "hyper-sensitive" mindset among a variety of identity groups who see themselves as sharing a common characteristic as "victims". Ironically, this is a perspective that only now appears to be expanding to include white males who are not embittered Neo-Nazis. This new constituency is rapidly being molded into an identity group created from those long considered by the other "identities" to be the "victimizers" who were repeatedly 
accused for the past twenty or thirty years as being responsible for the ills of the nation and the world. White males have come to be members of the camp of the "put upon" and the "victimized" rather late in the game but they can be increasingly expected to take action to identify and protect what they perceive to be their interests. ${ }^{11}$

This shift can be seen in such areas as the expanded support for Republican political candidates by working class blue collar white male voters who have traditionally voted Democratic and also includes more women than might be thought. ${ }^{12}$ Another indicator may be found in the recent Internet creation of what are being called "White Student Unions" on university campuses [allegedly and quite possibly by students] in the US and Australia. At this point it is not known if the Unions are real student-driven organizations or simply the creations of Internet "trolls". But since what is going on in the various "specialized" identity movements is implementation of strategies involving control of language and "spaces" there is a definite irony in the fact that other than the argument that basically reads: "White Men are the oppressors and are therefore not allowed to continue their oppression by organizing and using the same tools as the oppressed and subordinated"--there is legitimacy in creating organizations that are dedicated to identifying and preserving identity group interests.

\footnotetext{
11 Doug G. Ware, "Census: White children to become minority by 2020: The USCB says by 2020 , white children will make up less than half of the nation's minors, and all whites will fall under that mark 24 years later." March 5, 2015, http://www.upi.com/Top News/US/2015/03/05/Census-White-children-to-becomeminority-by-2020/9751425612082/.

12 See, e.g., Philip Rucker and Robert Costa, "Republican hopefuls agree: The key to the White House is working-class whites", Jan. 13, 2016,

https://www.washingtonpost.com/politics/republican-hopefuls-agree-the-key-to-thewhite-house-is-working-class-whites/2016/01/12/fa8a16aa-b626-11e5-a76a0b5145e8679a story.html
} 
In that regard consider this statement by an organizer of one of the Australian university White Student Unions.

"We're a genuine group, we're not doing it to troll anyone," he told news.com.au. "If you roll up to any university these days you'll have gay safe spaces, Muslim safe spaces: in the last four or five years it's become very politically correct." "That's great. I'm as PC as they come. We're staying within the narrative. All we want is equality." He said he was "absolutely" expecting a backlash, but wanted to "test the boundaries of what they're willing to acknowledge”. "We just thought, why not? Everyone else is doing it, why can't we do it? Anecdotally we have a lot of support from the ethnic students," he said. "Our main antagonists are actually the older, white academics. These people say they're all about equality. The academics try to build this narrative that nobody supports this stuff, but it's happening. We're just using that language ourselves." 13

The White Student Unions appear to be so socially unaware that they do not understand that the power to condemn is only a one-way street. This has been demonstrated in university speech codes that reflect academics' agreement with the suppression of open discourse even in the university setting where we were silly enough to "think" that independent and challenging thought was paramount. Seth Stevenson describes: "These codes have their roots in theories, which gained favor with campus radicals in the 1960s, contending that (as Silverglate and Kors put it in a book they cowrote) '[i]f the powerful and the weak were required to play by the same rules ... the

\footnotetext{
${ }^{13}$ Lauren McMah and Frank Chung, "Behind the 'white student unions' springing up at Australian universities", news.com.au, December 2, 2015. http://www.news.com.au/finance/work/careers/behind-the-white-student-unionsspringing-up-at-australian-universities/newsstory/1ec829bb66b30a8e98544784f1746b75.
} 
powerful always would win.' In other words, this theory goes, the disadvantaged need different rules. What's more, these rules should extend to speech, not just to actions, because speech can be just as powerful and hurtful.” 14

The members of the classes of "sensitives" are made up of all social groups, genders, races and sexual identities and orientations. Among their core characteristics seem to be that they cannot tolerate critique in reverse, they see themselves as the center of the universe, have no sense of the discipline and hard work that is required to excel, couldn't recognize exceptional quality if it hit them in the head or are threatened by excellence because it makes them "feel" inadequate, and consider their own emotional state to be the be all and end all of the world they inhabit. If all this were not enough, an undeniable aspect of their behavior is that they are quick and ruthless to offer criticism of the most banal and poisonous sort when their extremely delicate sensitivities are offended.

Members of the "hyper-sensitives" are almost unbelievably thinskinned when they subjectively perceive someone might be "dissing" them or in a "guilt by association" statement "disrespecting" the narrow identity group to which they belong. They demand that whatever they say or do is deserving of respect and, "how dare" anyone fail to appreciate the legitimacy of whatever it is they do or say?

Ruth Sherlock writes, in "How political correctness rules in America's student 'safe spaces"” 15 about students changing how education works, including demanding the elimination of words and ideas that oppose their own. Sherlock indicates students claim that

\footnotetext{
${ }^{14}$ Seth Stevenson, “The Thought Police," January 2003.www.bostonmagazine.com, Archives.

15 Ruth Sherlock, "How political correctness rules in America's student 'safe spaces'”, November 28, 2015.

http://www.telegraph.co.uk/news/worldnews/northamerica/usa/12022041/Howpolitical-correctness-rules-in-Americas-student-safe-spaces.html.
} 
they suffer emotional "trauma" when subjected to such things and "now speak about "micro-aggressions", "trigger warnings" and "safe spaces". One problem is that this injects such uncertainty into the process of discourse that the "safest space" for a teacher, scholar, or student who is not a member of a protected identity group is to simply be quiet.

This intimidated or prudential quietude, however, betrays the basic ideal of the university, including the students who need to be prepared for a world that does not follow the rules of a sequestered "hot house" environment and for teachers and scholars who are attempting to engage in a fundamental process of communication and research. Peter Suber sought to cope with this dilemma in his observation that: "it is important not to allow discourse to be subordinated to repression and speech codes, even while acknowledging that some restrictions on the deliberately harmful speech are possible.” 16

While the idea of "safe space" was first used to describe a refuge for people exposed to racial prejudice or sexism Sherlock reports that it has a changed meaning. Now "it often implies protection from "exposure to ideas that make one uncomfortable", according to Nadine Strossen, a prominent law professor and former head of the American Civil Liberties Union. [She adds] This hesitancy to engage in the dialogue of debate - and, in its most extreme form, the sense that hearing opposing opinions can cause damage to the psyche - has seeped from the campus to the classroom." 17

A similar tactic to demands for a "safe space" for specific identity groups has arisen under the concept of a teacher's responsibility to provide "trigger warnings". Sherlock writes that: "The introduction

16 "Peter Suber, "Unsimplifying Political Correctness: When the Right and Left are Right and Wrong," http://www.earlham.edu/ peters/writing/pc.htm, vis. 6/23/04 @3:48PM. [This essay originally appeared in The Earlhamite, 111, 2 (Spring 1992) 2325].

17 Sherlock, id. 
of "trigger warnings" may have been designed to protect people who have suffered serious trauma, but critics fear they are now a means to prevent the free discussion in class that is an essential part of academic learning. "The language of trauma, which started as a term to describe extreme events, started to be used much more loosely," [Harvard] Prof [Jeannie] Suk said. "So trauma is now colloquially used to mean lots of different things including non-extreme, even everyday events." 18

This leads to a recent report of a student's indignation and hurt feelings at an Oklahoma college. The report indicates that following a chapel sermon dealing with a First Corinthians biblical passage on love that a student at Oklahoma Wesleyan University (OKWU) felt "offended" and "victimized" "because the "homily on love made him feel bad for not showing love," he explained. "In his mind, the speaker was wrong for making him, and his peers, feel uncomfortable.", The university's president Everett Piper responded through a post on the college's website. He criticized "self-absorbed and narcissistic" students and stated: "This is not a day care. This is a university".... [Adding] "Our culture has actually taught our kids to be this self-absorbed and narcissistic. Any time their feelings are hurt, they are victims! Anyone who dares challenge them and, thus, makes them 'feel bad' about themselves, is a 'hater,' a 'bigot,' an 'oppressor,' and a 'victimizer.", 19 I particularly liked the "not a day care” statement.

\section{Unintended Secondary Effects and "Collateral Damage”}

\footnotetext{
18 Sherlock, id.

19 Todd Starnes, "University president rebukes 'self-absorbed, narcissistic' students", http://www.foxnews.com/opinion/2015/11/30/university-president-rebukesself-absorbed-narcissistic-students.html?intcmp=hplnws
} 
I have always supported affirmative action policies. I began my legal career as a Legal Services and civil rights lawyer prior to becoming a clinical teacher deeply engaged in the representation of poor and disadvantaged people. I have trained public defenders and Legal Services lawyers and served as counsel to a Black on Black anticrime committee and was almost a Founding Faculty Member at the newly established Florida A \& M University law school but the person who was supposed to be the first dean of that law school was sabotaged at the very last minute by external political machinations even though he had been the choice of the FAMU committee at this "historically black" institution charged with selecting the law dean.

The point is that my life has been spent in teaching, activism and scholarly work in which fairness and justice for disadvantaged people have been central elements. One understanding that has always driven my career choices has been that our American history in areas involving employment and other opportunity in race and gender is dismal. There was large-scale and pervasive long-term discrimination to the point that racial and ethnic minorities as well as women were marginalized and denied a fair opportunity at being hired in the first place or being promoted once hired if that did occur. That is an unforgivable social evil that we are trying to rectify and must continue to do so, and do it better.

But even with the necessity of installing fair hiring and employment practices one social and psychological reality is that there are positive and negative consequences of that act in a system ostensibly based on non-discrimination for all. A reality of fair practices laws in hiring, management and promotion is that in some instances they are undeniably an act of discrimination against qualified people who had nothing to do with creating the behaviors that led to the passage of affirmative action laws. Our political system had important and legitimate reasons for enacting the legislation but we must be clear that the laws legalize another form of discrimination and there is "fall out" from that fact. The point I am trying to make here is not that the laws were illegitimate but that as I will discuss below, such major 
"events" have what might be thought of as "expiration dates" in which over time they produce effects that are both positive and negative.

Correcting the pernicious effects of decades and generations of systemic discrimination that deprived the members of disadvantaged groups of deserved opportunities is a noble goal. How to do it effectively and with the minimum of harm to the underlying ideals, the relations between groups affected positively and negatively. Dealing with the inevitable impacts of the rules on new groups of people who had nothing to do with the past discrimination but are required to pay part of the price imposed by steps aimed at corrective justice is something we are not very good at.

Yet, after fifty years of the grant of hiring and status preferences to those groups that were wrongly treated historically, a side effect is that we have entrenched another system with pernicious effects after decades of affirmative but necessary discrimination seeking to achieve corrective justice for the historically disadvantaged. This system has deprived members of a newly disadvantaged group who had not been part of the historical "sin" of discrimination against minorities. To provide a buffer against what is an obvious form of discrimination we have witnessed the invention of "white privilege", "white supremacy" and "micro-aggressions".

These labels are an unsubtle version of the doctrine of Original Sin applied through generations of a specific racial characteristic to people who were not responsible for the past discrimination. They are a form of "collective guilt", of "guilt by association" and punishment of wrongdoers' descendants to the third and fourth generations as seen in Biblical passages. Anyone of any intellectual capacity would immediately condemn what was occurring as a new form of discrimination and racism if the people involved were not mainly of European ancestry in the category we refer to as white and the specific group in that category we call male. 


\section{Applying Newton's Third Law to Social Consequences}

In the category of people harmed by new rules based on actions they personally were never involved in or for discriminatory attitudes they reject, we can draw a comparison to the concept of "collateral damage" in war where innocent civilians are killed or maimed in attacks aimed at the real "bad guys". Some of the damage is inevitable and necessary but we should not expect the victims and their families or targeted communities to "smile brightly for the camera" and announce how happy they are about what is taking place.

One reality, as Lord Acton warned, is that power always corrupts. It is undeniable that anti-discrimination laws are a grant of power to people who were previously largely powerless. My aim here is not to develop an argument about the legalities and constitutionality of "legal discrimination" aimed at achieving a type of corrective justice aimed at remedying past injustices, but to mention the inevitable resentments and psychological effects such a system creates not only on the values and mindsets of those disadvantaged by the laws but by those who are benefitted by their new empowerment.

For the purposes of this discussion it is useful to look at the language of law covering the area in question and to think how law leads to the shaping of behavior and to institutional edifices erected to implement the requirements. I suggest that the legal statements contained in the examples quoted below have produced impacts on our society that after decades of expansion, addition of new identity groups, court decisions and administrative behavior have increasingly pitted racial and gender groups against one another as the rules have become more deeply embedded in society and expectations and demands increased. What has been taking place over the past fifty years is highlighted in the passages below representing characteristic rules by which employers are expected to regulate their hiring, management and promotions behavior. 
[The Company] provides equal employment opportunities (EEO) to all employees and applicants for employment without regard to race, color, religion, sex, national origin, age, disability or genetics. This policy applies to all terms and conditions of employment, including recruiting, hiring, placement, promotion, termination, layoff, recall, transfer, leaves of absence, compensation and training. [The Company] expressly prohibits any form of workplace harassment based on race, color, religion, gender, sexual orientation, gender identity or expression, national origin, age, genetic information, disability, or veteran status. ${ }^{20}$

This all sounds great. But we should ask ourselves what kind of system it has created. What are the secondary and tertiary unintended consequences of such a system? In that regard I am not referring to the "law" but to the behavioral, perceptual and psychological impacts of such a system on those who are the intended beneficiaries and on those who are clearly relegated to disfavored status?

In considering the total systemic effects of a particular law it can be useful to apply another kind of law, and here I suggest we think about applying Newton's Third Law in a social sense. Newton's formulation, "for every action there is an equal and opposite reaction", has implications for what is occurring in American society. The simple yet troubling fact is that discrimination and the selective favoring of something -including classes of people with special identifiable characteristics such as race, ethnicity, gender and gender identity as well as sexuality - is an extremely major action that alters the conditions of society and is intended to do so.

Creating such a powerful and comprehensive strategy through the power of law and its enforcement mechanisms is a fundamental

20http://www.shrm.org/templatestools/samples/policies/pages/cms_005022.aspx\#st hash.CR61ma4Q.dpuf. 
action that inevitably produces a range of reactions of comparable scale within a social system. The problem is that some reactions are intended while others occur in ways that were both foreseeable and unforeseeable. Those reactions are not only those that advance the interests of the favored classes intended as beneficiaries of the original legal action, but by those disfavored groups and individuals in society who suffer the negative "downside effects" of the strategy.

No action is cost-free. In seeking "corrective justice" there are inevitable "corrective injustices" produced. Honest logic allows no other conclusion. If the answer to this by the newly empowered groups is to say "That's too bad, but it's our turn now"-and I have had such statements actually made to me by a law school administrator with whom I dealt-then anyone who thinks that this does not create an "us versus them" response on the part of many people really does not know anything about human nature.

The situation becomes even more complex when we admit that given all the continuously multiplying categories of specially favored classes and protected characteristics mentioned above in the example of the law to which employees are subject, it is not an exaggeration to state that the only remaining class of people who are not protected and who are placed at a disadvantage in promotion and hiring are heterosexual white males of European descent. Oddly enough, this is causing many in that group to think of themselves explicitly and for the first time as having a unique "identity".

This is something I absolutely hate to see developing but as I am trying to suggest in this analysis it is an inevitable consequence of decades in which all other groups have been granted special status under the Rule of Law even while it has become a bad joke that the only safe target for "politically incorrect" speech and discrimination are white males. When those white males were dominant they could mostly laugh off the "inconvenience" the legal changes and linguistic developments represented by political correctness, but now white males are hearing from a variety of sources that they will be an 
increasingly impotent part of a multicultural American society in only a few decades. They already know they are low on the priority list for employment due to the fact that job announcements strongly indicate a desire to have women and minorities apply. One would have to be illiterate not to read "the writing on the wall" and this means that for themselves and their children there is an increasing likelihood of reactions and reactive strategies.

\section{What Did We Think Would Happen?}

People are increasingly lamenting about the perception that there is a rise in racially troubling attitudes in the US. Of course there is such an increase, but the tension is far less a racial or gender animus than it is resentment over loss of power on the one hand and being subject to behavioral oversight that is continuously looking at whether you may have violated one of the highly subjective rules set out in the workplace examples mentioned above.

In this ultra-sensitive world it is also far too easy to misinterpret cultural disapproval for racism. Racism is based on bias against a characteristic that has nothing to do with an individual's quality or merit and is ignorantly projected to an entire group. Cultural disapproval relates to behavior that is chosen. Even if that behavior is mainly done by a subset of a culture that does not mean it is racist. For example, I detest "Gangsta rap" in its most obscene and violent aspects. Even though the vast majority of its performers are black my dislike is not based on their "blackness" but because I don't like crudeness, obscenity, disrespect for women and so forth. If someone decides to call that attitude "racism" then all I can say is "too damn bad!” because it isn't.

Think about how the rules against all forms of discrimination set out above work not only in theory but in the realty of the workplace. If you are a white male manager and have arguably done something found to subjectively violate the new rules, you can suddenly find yourself out of a job or ordered to undergo multiple sessions of 
"sensitivity training" through which you are shown the error of your ways by people with their own political agendas and attitudes. As part of repairing your "sensitivity deficiency" once you are prejudged as being "insensitive", bigoted, sexist, racist, homophobic, too "Christian", or unwilling to admit that you only occupy your position due to "white privilege" or commit any more "micro-aggressions" that are in the opinion of the beholder you might as well "hit the road”.

On the issue of mandatory "sensitivity training” in a "you've got to be kidding moment"--but they weren't--the Black Lives Matter students who issued fifty Demands to the University of North Carolina in mid-November 2015 pretty much reprised the dictates of Mao Tse Tung's youthful Red Guards in China's Cultural Revolution as they made their position clear as to the need for widespread and comprehensive "sensitivity training" including the fact that they were to be the ones in charge.

The BLM students and protesters declaimed: "We DEMAND that the University incorporate mandatory programming for all University constituents (students, faculty, staff, administrators, deans, chairs, etc.) that teaches the historical racial violence of this University and town as well as a historical and contemporary look at the ways in which racial capitalism, settler colonialism, and cisheteropatriarchy structure our world. This will come from an ungraded course created and facilitated by a coalition of students as part of a broader task force of workers, students and staff. There is an acceptance of oppression as the norm at this University that must be called out and addressed. The program will be vetted by a University professor of our choosing." [Emphasis added]. ${ }^{21}$ All I can say to that is "Go back to China."

\footnotetext{
${ }^{21}$ November 19th, 2015, A COLLECTIVE RESPONSE TO ANTI-BLACKNESS. To the UNCChapel Hill Administration, UNC-Chapel Hill Board of Trustees, UNC Board of Governors, North Carolina General Assembly, and other governing bodies. https://docs.google.com/document/d/1r1Rp3Tn8sPlfbn_b03vQXOVRnDpaDvB_ctaBK XvbpNU/edit?pli=1.
} 
I actually spent more than five minutes on Google trying to find out what "cisheteropatriarchy" means. Google and many other users are as confused as I am. It is comforting to be reminded that college students are still sophomoric and that in many instances they strive mightily to achieve pseudo-intellectualism. But just imagine having to undergo a university or workplace "re-education" program in which your "trainers" used terms such as cisheteropatriarchy. There had better be metal detectors at the doors.

The point I am making is that if someone is part of an identity group (for example, "white heterosexual males") representing a segment of society from which rights and social goods are being extracted and redistributed, even if the individuals are entirely blameless for real and imagined historical deprivations to other identity groups, then it would take a saint not to resent or resist what was taking place. In other words, after decades of progress in race relations and civil rights generally we are entering a phase in which relations are almost surely going to become more virulent and uncivil. Unless we figure out how to more effectively bridge the disagreements between competing identity groups the picture is going to become increasingly ugly.

\section{Identity, Identity, Identity}

UCLA researchers who completed a recent study on the racial and population demographics of the United States suggested that: "the results are related to whites feeling threatened in a way that is distinct from their concerns about economic competition or clashing cultural values. They concluded that the demographic changes are threatening whites' sense that they best represent the American identity. .... The "threat to identity," [one researcher stated] "is often 
overlooked in discussions about why whites are uneasy about changing demographics." 22

This shift in perspective and societal demographics is a key element in a set of trends that presents a foreboding picture for America's future. No matter what the people in the newly subordinated category of "whites" and "white males" do, they are open to charges that the institutional system itself is structured in a discriminatory way as a matter of its history. This produces the accusation that any treatment an upset person receives who is part of one of the favored classes is inherent institutional discrimination.

For the anti-discrimination laws, and supportive institutions such as the EEOC to remain in place, an altered test was needed for what constituted discrimination and workplace harassment. Since so much of discrimination was said to either cease or "go underground" and become subtler another descriptor had to be put into play. If people generally were no longer engaging in overt discrimination but there were still differences in representation of the protected identity groups, the answer was that the discrimination was covert, or subconscious bias, or if not biased in terms of an individual's conscious or subconscious actions, then it had to be systemic or historical institutional bias. Otherwise the legal and enforcement regime would have no reason to exist on the scale that has developed over the past fifty years.

The bottom line is that a result of discrimination becoming subtle or even disappearing but with inconsistencies and statistical anomalies remaining in access to jobs and opportunities, is that it has become more difficult to identify direct conscious discriminatory acts that violate the law. This changing nature of discrimination, including in

\footnotetext{
22 Stuart Wolpert, "Soon to become a minority in the U.S., whites express declining support for diversity, UCLA psychology study finds", October 02, 2014.
} 
many cases its actual elimination, has led to an increase in accusations and arguments such as "white privilege". This has also produced a kind of interpersonal "mindreading" in which a speaker or actor is required to understand the impact of language and behavior on someone who is a member of an identity group that has been granted power by the law. That protected identity group member possesses the subjective power to define, invent and assert a violation. This includes the apparent ability to read the speaker's mind about what was intended by words and actions and, quite importantly, to initiate processes that impose serious costs and consequences.

An inevitable result of this new world of subjectivity and taboo linguistics is a resentful, fractured society in which many people are playing "language games" because that has become the "coin" by which advantage is gained and disadvantage imposed. One key finding of a study conducted by UCLA doctoral student Felix Danbold and Professor Yuen Huo is that: "white Americans' favorable views of diversity tends to diminish if they understand that whites will soon be a minority in the U.S. White Americans may view diversity and multiculturalism more negatively as the U.S. moves toward becoming a minority-majority nation..." 23

\section{Whites as the Emergent "New Minority"}

Demographic projections indicate that whites will become a numerical minority by 2045. There are various causes that include higher birth rates among minorities, immigration mainly from other countries with populations that in America are minorities and the fact that whites are dying at a higher rate as "boomers" expire and

\footnotetext{
${ }^{23}$ Stuart Wolpert, "Soon to become a minority in the U.S., whites express declining support for diversity, UCLA psychology study finds", October 02, 2014. "UCLA psychologists report." http://newsroom.ucla.edu/releases/soon-to-become-aminority-in-the-u-s-whites-express-declining-support-for-diversity-ucla-psychologystudy-finds.
} 
younger whites are not repopulating their ethnic group at the same volumes as minority groups.

In fact the 2045 date for becoming an absolute minority relative to the total combined population of what will then be other minority groups is misleading for several reasons. One is that minority births will exceed white births in 2020, only five years from now. ${ }^{24}$ This will have significant if unknown good and bad implications from the perspective of identity group competition and cooperation. The competition can be expected to become savage when we take into account that jobs are disappearing in many sectors due to globalization and automation. If the job market compresses while the population seeking those positions expands, the social tension and intergroup competition will be severe across the board.

\section{Reformulated Alliances Between Identity Groups}

Part of what we can expect as this occurs is that not all identity groups are "born equal". Nor are they hermetically separated from each other. Much of the analysis on the projected demographic shift almost seems to assume a "white" versus "all others" world as the system changes. This will not be the case. It is far more likely that many whites will create joint political strategies with Asians and what are referred to as "white" Hispanics. The strong political support for Marco Rubio and Ted Cruz is an example of the process that is already developing and it is considerably more broad-based

24 Doug G. Ware, “Census: White children to become minority by 2020: The USCB says by 2020, white children will make up less than half of the nation's minors, and all whites will fall under that mark 24 years later." March 5, 2015, http://www.upi.com/Top News/US/2015/03/05/Census-White-children-to-becomeminority-by-2020/9751425612082/. "The United States Census Bureau this week projected that five years from now, white children will be in the minority -- and by 2044 whites will be wholly outnumbered by nonwhites. The projection analysis released by the USCB cites multiple reasons for the change in population makeup, most notably that the number of immigrants arriving in the United States is higher than ever. The report also said that birth rates among white couples is on the decline, while nonwhite couples are experiencing a baby boom of sorts." 
than many realize. There will also be increasing connections made between blacks and whites at the educational and career levels represented by Republican candidates such as Ben Carson and Herman Cain, people who are trying to live lives according to the American Dream as they see it rather than operate on a platform that is seeking to rip apart critical American institutions. Consequently, the "white minority" language does not reflect the realities of politics and power.

In this process, however, we face a seemingly intractable challenge of how we can deal with the consequences of a tragically inadequate policy that segregated our cities, is still providing poor and inadequate education to a large number of black and Latino students, and is sending many of those students into the world totally unprepared to participate in it in a productive way. This is America's shame and we still do not know how it can be rectified. Although there has been enormous progress over the past fifty years in the creation of opportunities for many black Americans the harsh reality is that we have defaulted on our obligations and allowed several generations of young black and Latino minority individuals to be undereducated, under-supported, undertrained and unemployed.

As the employment system "tightens" and decent jobs become more scarce the overall system will experience continual strife and massive expenditures as a consequence of its betrayal of generations of minority youth who are already being incarcerated in numbers significantly greater than their proportion of the population. This does not mean that the crimes are not being committed but that we have consistently avoided the intelligent and tough policies required to remedy the sins that we "have wrought" with our minority communities.

\section{Sensitivity, “White Privilege”, “Micro-Aggressions” and Unilateral Perceptual Subjectivity}


A strong reaction is what we should expect when a specific group finds itself seriously disadvantaged in hiring and promotion and when there is suddenly a cleverly invented set of terms such as "white privilege" and "micro-aggressions". When such terms come into play in a system in which it is admitted that most overt racial and gender discrimination has disappeared or been reduced to a level of subtle long-term institutional biases built into how an institution behaves, even if its inhabitants themselves engage in no obvious discriminatory behavior, then it represents a system in which "invented" or wrongly perceived or misinterpreted actions are challengeable.

The challenges may often not be because of anything the current actors did but due to the emanations of prior generations of institutional actors. This understandably gets a bit tiresome for many of those subject to the new rules of nuance, subtlety and "mind of the beholder" perceptual subjectivity. It represents a situation in which there can be a great deal of overreaching by those perceiving or claiming to perceive others' intentions accurately, or attempting to construct a rationalization for why they were not hired, promoted, respected, or treated equally as they perceive the treatment. A result of all this is a system in which people who are the potential targets of making decisions in an institution to hire, promote or even fire an employee considered inadequate are "walking on eggshells".

As indicated earlier, we are not talking legalities at this point but the effects legal rules can have on what could be called the "deep structure" of a society. Part of the analysis includes how elements of that society come to view themselves and their protected interests and entitlements. It also includes the creation of identity associations for purposes of "belonging", as well as defensive and offensive rationalizations to protect one's positions. A result of such behavior is the generation of "fracture lines" between their identity groups and others they see as trying to take away rights and social goods or who are trying to retain possession of rights and social goods desired by a competing newly empowered identity group. 


\section{A Few Personal Examples}

Sometimes discussions about vital issues can possess an abstract character that confuses the situation. At this point I want to offer several personal examples that might suggest the difficulty of the situation about which I am writing.

Tom D. and Jazz. When I was in college I had a friend named Tom who happened to be black. One day we were talking about things and the subject of music came up. During the discussion I mentioned that Tom liked jazz, to which he looked at me and asked, "Why did you say I liked jazz?” I stared at him a moment and replied "Because I've been in your room while you were listening to jazz and you have maybe twenty jazz albums on your shelf", to which he said, "Oh. Yeah." We talked about it a bit and he admitted that he was almost automatically alerted to statements by white people that to him indicated an assumption about black people, including of course the classic "watermelon" and "fried chicken" which I had neither uttered nor thought about. I did say that I had no idea about the things that were thought of as attitudinal "signals" by black people, although I added that I assumed everyone liked watermelon and fried chicken so he would just have to bear with me on that. We remained good friends.

White People's Code Words. A much later discussion during a meeting to decide which potential new pledges to accept in the fraternity Tom and I belonged to also demonstrated it was not unwise or unreasonable for a black person to have suspicions about what lies behind language. One of the candidates was black and during the discussion two or three of the other fraternity members started arguing that this individual, also named Tom, was "lazy" and shouldn't be admitted because of that. First of all there was no ban on lazy people in our fraternity and since I was surrounded by a fairly large number of lazy white males in the room I felt compelled to challenge what they were saying as a not very subtle example of 
racism by use of a code word, "lazy". We were all supposed to understand the "coding" and "rally round the flag" and reject the candidate. It ended up that he was approved and was a solid member of the fraternity, a good "brother". The experience shows the reality of what most black people faced decades ago and still face in a world where racism has gone underground. If you read the anonymous comments to any Internet post in which race is an issue it is obvious that there is still a hardcore set of angry racist people "trolling" the Internet revealing rotten and vile attitudes that few would ever utter aloud absent the Internet's anonymity. This means that even though much discriminatory action has disappeared there is still a hard core of sexism, racism, anti-gay and other biases in our society.

My Way Or The Highway. Not all that long ago I attended the Women Law Professors session at an AALS Annual Meeting. At one point during the floor discussion a female law professor who was black stood up and admonished the other women in attendance. Her point was voiced very strongly and was that black law teachers did not want the white women law teachers to evaluate, discuss and critique what they said. She explained that "we know what we are talking about and what we want from you is support and agreement." While that may be a slight paraphrase it captures precisely the point that was being made. Essentially the statement was: "We are writing from our experience and space and your job is to accept what we say and be our advocates.”

This really goes to the heart of what is going on in universities and many political movements at this point. For those of us suffering under the delusion that universities and education exist to develop critical minds, to seek objective truths, and to challenge those in power who misinterpret and abuse their responsibility, someone asking and demanding that they are entitled to a "rubber stamp" of what they say and to full political support is asking too much. Yet that is part of what is going on in American society and in universities to far too great an extent and it is getting worse. 
Don't Ever Tell a Female Academic She Is Being “Irrational". Other experiences include a disagreement with a female faculty member about an issue about which I don't even remember the substance. During the discussion I responded to an assertion that I felt made no sense and stated that her argument was "irrational". Guess what I discovered? She turned red, raised her voice and ordered me out of her office. I had just found out two things. One was that few people like to be told they are irrational, and the other was that academic women take it badly because many feel that they are being marginalized by claims of rationality versus irrationality. Interesting lesson to be sure.

But she was making an irrational argument without adequate data. She was a tenured full professor who obviously had not suffered discrimination at least in the academic sphere. And, the odd thing is that we are often told through research that women operate more on the basis of emotion and empathy than men and that men tend more toward the rational side than do women. Yet her angered perception that was directly related to the use of a single word "irrational" was sufficient to trigger what then and now strikes me as an "over-thetop" reaction that nonetheless demonstrates the danger of hypersensitivity and the use of nuanced subjective micro-aggression claims.

One thing I have discovered during my years in academia is that there are very few female academics that have an actual sense of humor, or at least who can appreciate my incredible wit. Putting my own inadequacy aside I think there is a very significant difference between what men and women perceive to be humorous. "Locker room humor" is a regular aspect of many men's communications and they often treat each other with pretty savage and insulting jokes. Of course there are numerous situations in which workplace harassment is intended, but I also think that a fair amount of what is considered inappropriate and insensitive communication and behavior on the part of men is simply how men communicate with each other. We tease, insult, make fun of, "put down”, make stupid jokes about sex 
and almost anything else that are in "poor taste" and that we don't ever want anyone outside that context to hear or record and distribute.

The "male of the species" is not the most sensitive or delicate "flower" in the human "bouquet" and we do dumb and insensitive things because that is how we communicate, just like great apes grunt and roar and beat their chests. The problem is that if done in a setting with a woman it will be seen by them as tasteless, discomforting, insensitive, harassing, malicious, etc. The simpler truth is that while some men are biased against women, men often insult each other with ruthlessness as part of the "male ritual" while women are much offended by that behavior.

“Insensitivity" As Reverse Coding. During a dean search at my law school we spent months identifying, interviewing and doing background research on candidates. At the end of that time and after all the Dean Selection Committee reports and faculty reviews had been completed we met as a full faculty to make our choice between candidates. When we got to discussion of the individual who appeared to be the favored candidate among a majority of the faculty a black female law professor came into the room almost breathlessly and asked to speak on the candidate. She then offered the fact that she had just gotten off a telephone call with someone she knew from the person's home institution and had been told that he was sometimes "insensitive". We asked for specifics but were provided none beyond that description. The until-then favored candidate was not approved because he was allegedly "insensitive" although we never knew any details, was not told who the person providing that description was, what relationship they might have had or anything else that might have provided detail, facts or truth. With this kind of behavior occurring in an institution of higher education why would we be surprised at the decline in standards and lack of integrity among educators and students? 
"Blackballing". Once I was sitting around prior to a committee meeting with two colleagues who were of African descent. The committee's function at that moment was to review faculty proposals for summer research grants and the number of proposals exceeded the number of available grants. I mentioned during our discussion that we would have to "blackball" several proposals because of the limited funds and we needed to discuss criteria that could be used to that end. My two colleagues who I counted then and now as friends jumped all over me for my use of the word "blackball". I said in response, "What the hell are you talking about?" They responded that in that context "black" carried negative connotations because it meant the proposals were of a lesser quality and their reasoning was that it ["blackness"] could be associated with racial judgments about black people.

I asked whether they were serious because in my frame of reference it seemed that they must have been putting me on. They indicated they were serious about it and we discussed their point of view and my own in which as far as I knew there was absolutely no connection to race in the use of "blackball". Their argument was not an historical one but based on that fact that "blackballing" or rejecting someone carries negative implications of someone being unacceptable and reinforces the thought process in which anything "black" is bad, including people. I told them that since I tended to dress in mostly black clothes and Hopalong Cassidy wore black and he was good and the Lone Ranger wore a black mask, I would have to think about their argument since the idea of the blackball has older roots that had nothing to do with race. But what the interchange does show is that these race, gender, sexuality and religious "things" have us all operating from different and sometimes weird frames of reference.

It also shows that what an individual or group prefers or interprets as insensitive, benign or offensive inevitably differs radically based on the speakers and receivers. I fully admit that as a boy I loved the story of "Little Black Sambo" and that the lesson I took away from it 
was that Sambo was a smart and very fast kid who survived a tiger attack. In fact, when I was about eight years old I found myself in a horse pasture with a stallion that apparently didn't like little boys and started chasing me with obvious ill intent. There was one big tree in the pasture and I ran to it and ran around the tree three or four times with the horse snorting and chasing after me but having to take much wider loops than I did. I was lucky because the tree was close enough to the fence that I was able to race to it and duck under its boards when my pursuer was still on the other side of the big tree trunk. Sambo showed me the way and has always been my hero. For me, Hattie McDaniel in Gone With the Wind was a very positive, strong and forceful woman who I admired even as a young teen when I first saw the movie. Yet these representations of black people are seen by many black people as racist. I see them as strong and intelligent people, not to mention that Ms. McDaniel won an Oscar for Best Supporting Actress for her role as Mammy. I guess we all see things through different lenses and prisms and this is why I am troubled by the movement toward one-sided "micro-aggression" subjectivity and increasing control over discourse by specific identity groups whose "lenses" are rigidly focused and non-adjustable.

Don't Talk To Journalists. A reporter from the Cleveland Plain Dealer once interviewed me about the state of Cleveland State's College of Law where I taught. One of the main topics he asked about was why the law school had a generally but marginally lower bar passage rate than CWRU's law school. This was a sensitive topic and we spent as much as 30 minutes discussing its varied aspects. Part of that discussion involved my explaining that CSU had a long-term unique program that sought to identify the merits of "non-traditional" applicants [our Legal Careers Opportunity Program or LCOP] and that a percentage of our admissions involved minorities and women who we determined had significant promise for success as law students based upon varied factors in their records for the period after their undergraduate degrees were achieved. As a rule, their LSAT scores and undergraduate GPAs were not at the top of the method we used to evaluate applicants but as well as we could 
we tried to determine the degree to which their post-college experiences and maturation indicated a strong chance at success.

It was a fact that some of the students admitted through this program did not pass the bar examination. It was also a fact that those students tended to be African-American or females who were significantly older than women students who came straight to law school after college. In the discussion I indicated a strong, facultywide commitment to the LCOP program as one that provided opportunity for applicants who came from urban educational backgrounds that quite often did not adequately prepare them for performance on high-intensity academic examinations or manage to develop their writing skills. I suggested that these deficiencies were not intellectual as opposed to technical and methodological and also that law school did not do enough to rectify that problem. As to the more mature women, many of whom were coming to law school after raising families and being away from the academic world, I put forward the idea that test taking is a skill and methodology that erodes when not done regularly and that the sporadic nature of the law school exam-taking enterprise would not necessarily prepare such students for what they faced.

The news report came out in the PD's morning edition and as I parked my car in the faculty lot I ran into a black law professor who immediately blurted out "I don't believe you said that!" I said, "What are you talking about?" He replied, "That the law school's bar passage failures are because of minority students and women." More than a little stunned I responded, "I didn't say that. I said that we had the LCOP program to provide opportunities for students we thought deserved a chance and that because of limitations in their educational backgrounds or time away from intensive test taking they had more trouble with tests such as the LSAT and then the bar exam than our more traditional students who come in with higher predictors in the LSAT and undergraduate GPAs." I added that we had spent quite some time discussing the nuances of the issue and he responded that the reporter had condensed that discussion into one 
sentence that blamed the law school's bar passage rate on minorities and women-one sentence stated as a conclusion he attributed to me after a half hour discussion.

He said, "I believe you but the reporter sure didn't do you any favors." We went into the law school and the article was the talk of the building. Paul and LaVerne, key staff members who were African-American laughed at me and told me they knew I would never have said what the PD reported, as did everyone else in the school. They knew me, knew how I felt about racial justice issues, and trusted me.

But the fact that my friends and co-workers trusted me that also highlights the problem with discussions and statements about race, gender, and nearly any other issue of consequence in our society. No one trusts anyone from another identity group. Everyone is now "running a game" to make themselves look good or someone else look bad in an ongoing maneuvering for power, advantage and control. In the situation described above, there was an immediate letter to the editor of the PD by a woman I had never met claiming I was a sexist and a racist. Another woman who had never met me or contacted me to ask about my actual views called the law dean and demanded that I be fired. It basically ended when another woman wrote a letter to the PD stating that the one sentence was clearly not a quote, that I had not said it, and the sentence was obviously something paraphrased by the reporter. She also said that if you read the actual article in which the sentence appeared it was quite obvious that the sentence did not reflect what I thought on the issue.

The point is that any discussion of such volatile issues can explode on us and that we can say something wrong or that someone can misinterpret what we say, or that there are "trolls" who are willing to turn the most innocent statement into a cause celebre they can use to their benefit. Al Sharpton's justifying response to the exposure of Tawana Brawley's false claim about being raped by six white men-"But it could have happened that way to others" so the "narrative" 
was still a legitimate political device even if the rape never occurred-offers an example of the depths to which our political discourse has fallen on any issue of consequence. The fact that this behavior is getting worse and will become even more common as identity groups maneuver to obtain and preserve power represents an ominous crisis for American and Western European societies.

\section{Conclusion}

I will wrap up this analysis with the thoughts of two of my favorite writers, Martin Buber and Carl Jung. In The Undiscovered Self, Jung asserts: "[T]he gift of reason and critical reflection is not one of man's outstanding peculiarities...." [He adds, tellingly] "Rational argument can be conducted with some prospect of success only so long as the emotionality of a given situation does not exceed a certain critical degree. If the affective temperature rises above this level, the possibility of reason's having any effect ceases and its place is taken by slogans and chimerical wish-fantasies." 25 Can we think of any way in which Jung's words apply to our current social and political situation?

Maurice Friedman relates Martin Buber's view that: "Whether he takes refuge in individualism or collectivism, the man who flees answering for the genuineness of his existence is marked ... by the fact that he can no longer really listen to the voice of another. The other is now only his object that he observes. But true dialogue, as Franz Rosenzwieg pointed out, means that the other has not only ears but a mouth. .... Only if real listening as well as real talking takes place will the full possibility of learning be present...." "Only through genuine listening, and not through any mere feeling of group unity, will the full potentiality of any group as a group be realized.”26

25 C.G. Jung, The Undiscovered Self 12, 13 (Mentor 1957). Translated from the German by R.F.C. Hull.

${ }^{26}$ Martin Buber, The Knowledge of Man 40, 41 (George Allen \& Unwin, London, 1965); edited and with an Introduction by Maurice Friedman, translated from German by Maurice Friedman and Ronald Gregor Smith. 
Finally, as Buber warns in language that seems entirely relevant to our present state of affairs even though voiced five decades ago: "In our age, in which the true meaning of every word is encompassed by delusion and falsehood, and the original intention of the human glance is stifled by tenacious mistrust, it is of decisive importance to find again the genuineness of speech and existence as We. ... Man will not persist in existence if he does not learn anew to persist in it as a genuine We." 27

27 Buber, The Knowledge of Man, id at 108. 
